\title{
Ultrasonography for the management of reproductive disorders in dairy cows
}

\author{
Akhter M. ${ }^{1,3}$; Hoque M.N. ${ }^{2 *}$; Shamsuddin M. ${ }^{1}$; Alam M.G.S. ${ }^{1}$; Bari F.Y. ${ }^{1}$ \\ ${ }^{I}$ Faculty of Veterinary Science, Bangladesh Agricultural University, Mymensingh 2202, Bangladesh \\ $2^{2 *}$ Faculty of Veterinary Medicine and Animal Science, Bangabandhu Sheikh Mujibur Rahman Agricultural \\ University, Gazipur 1706, Bangladesh \\ ${ }^{3}$ Department of Livestock Services, Bangladesh
}

\begin{abstract}
Ultrasonography was used to confirm the diagnosis of different pathological conditions of cow's genital tract and to monitor the treatment outcome and conception rate for the improvement of reproductive disorders. A total of 54 subfertile cows with farmers' complaint for different types of reproductive problems were selected for this study. Confirmation and differential diagnosis of various reproductive problems was made by real time ultrasonography. Forty two cows received specific treatment against their reproductive disorders. The cyclic cows $(n=43)$ were bred using frozen semen and pregnancy was confirmed by ultrasonography at Day 30-35 after breeding. The reproductive problems diagnosed, were endometritis (27.8\%), metritis (7.4\%), pyometra (11.1\%), mucometra (3.7\%), follicular cyst (9.2\%), luteal cyst (1.9\%), mummified fetus $(1.9 \%)$, anoestrus $(22.2 \%)$, repeat breeding (3.7\%) and poor heat detection (11.1\%). Thirty one cows out of 42, receiving appropriate treatments, showed cylicity with overall $73.8 \%$ effectiveness of the treatment $183.3 \%$; poor heat detection, $60.0 \%$; endometritis, $100.0 \%$; metritis, $66.7 \%$; pyometra, $100.0 \%$; mucometra, $60.0 \%$; follicular cysts, 100.0\%; luteal cysts and 75.0\%; anoestrus). Among 43 bred cows, 37 became pregnant giving an overall $86.0 \%$ conception rate (100.0\%; poor heat detection, $84.6 \%$; endometritis, $75.0 \%$; metritis, $100.0 \%$; pyometra, 50.0\%; mucometra, 100.0\%; follicular and luteal cysts, $88.9 \%$; anoestrus and $50.0 \%$; repeat breeders). Ultrasonography can be used for improved diagnosis and management of reproductive disorders, to monitor treatment outcome thereafter and pregnancy success in dairy cows.
\end{abstract}

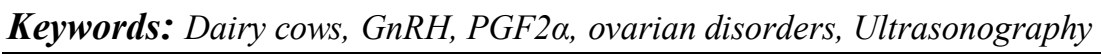

\section{Introduction}

The goal of reproduction management is to have cows become pregnant at a biologically optimal time and at an economically profitable interval after calving [17]. The main constraints of cattle reproduction is prolonged postpartum intervals to conception and low conception rate, which are the results of inefficiencies in the management of nutrition, estrus and AI services [16]. Early identification of non-pregnant dairy cows and heifers post breeding can improve reproductive efficiency and pregnancy rate by decreasing the interval between AI services and increasing AI service rate [4]. Thus, new technologies to identify non-pregnant dairy cows and heifers early after AI may play a key role in management strategies to improve reproductive efficiency and profitability.

Rectal palpation could be an accurate method for diagnosing pregnancy but is a poor method for resolving ovarian follicular distinction [14]. In contrast, ultrasonic imaging is a highly accurate and a rapid method for assessing ovarian structures as well as detecting cyclicity [6]. Hormonal examination to know the cyclicity is accurate but expensive and slow, moreover, it needs a specialized laboratory and the test can not be performed on farm [5]. But there is ultrasound machine to be used in veterinary practice, which is easily transportable to farms. In the bovine practice, ultrasonography has become an important diagnostic tool for evaluating the female reproductive system, where it is possible to view the entire reproductive system in a noninvasive manner [2]. Interest in ultrasonography among veterinarians and animal scientists began to grow in the early eighties, following reports on the usefulness of the technique in studying the reproductive organs of the cow [13]. Ultrasonography can be used efficiently for diagnosing reproductive disorders and the response to treatment thereafter [10]. The aims of the treatment of reproductive diseases are to reverse inflammatory changes that impair fertility, whilst enhancing uterine and ovarian defense and repair. The non-invasive nature of ultrasonography makes it an excellent clinical and research tool in the bovine reproduction [2].

The use of transrectal ultrasonography to evaluate reproduction in cows has enhanced our understanding of the ovarian and uterine processes during the estrus cycle, different pathologic sates and pregnancy in order to improve reproductive performance and genetic phenomenon. Even though the application of ultrasound in diagnosis and treatment of reproductive diseases in smallholder dairy farms has proved effective, the use of ultrasound as a management tool in Bangladesh is not widely distributed. Therefore, the present study was conducted to record different pathological conditions of the genital tract of dairy cows for 
more accurate diagnosis, to determine their proportions and to monitor treatment outcome for the improvement of their fertility in terms of conception rate.

\section{Materials And Methods}

2.1. Selection of subfertile cow: A total of 54 subfertile dairy cows were selected randomly for diagnosis and treatment of reproductive disorders. Farmers' complaints and ultrasonography were used to determine the subfertile cows. Farmers' complaints about the clinical cases were recorded and clinical signs of sub-fertile cows were noted down in TABLE 1 and 4, respectively.

2.2. Transrectal ultrasonography: Ultrasonography was performed by using a portable real-time B-mode transrectal ultrasound scanner (Pharvision Micro V10-3.5MHz, Piemedical,USA). Ovaries of individual cows were scanned twice at an interval of 10 days for confirmative diagnosis. Size of the ovary, follicles, CL and structures of uterus (before and after treatment) were examined and measured by using electronic calipers (vertical and horizontal measures) and their echo characteristics were described and compared (TABLE 4). Presence of CL, follicle or cysts in ovaries and conditions of uterus (either tonus or atonic and genital discharges) were examined on the day of diagnosis and then after treatment. Diagnosis was made on the basis of echogenicity of the images. Cows were classified into cyclic and non-cyclic cows based on the presence of a CL at least in one of the ovaries.

2.3. Treatment: After diagnosis based on history, clinical examination and ultrasonographic findings, the animals were treated following the protocol developed by [17] (TABLE 2).

2.4. Breeding of treated cows: A total of 43 cows out of 54, diagnosed with reproductive disorders were bred after giving proper treatment and management using frozen semen from fertile bull (TABLE 6).

2.5. Pregnancy diagnosis: The treated animals were examined for pregnancy diagnosis at day 30-35 after breeding by using ultrasound scanner. The pregnancy was confirmed by the presence of a visible fetus on viewing screen of the ultrasound machine which was irregularly shaped non-echogenic structures in the lumen of uterus.

2.6. Statistical analysis: The data were entered into Microsoft Excel worksheet 2007 and descriptive statistics were performed to determine the proportions of reproductive disorders in cows. Conception rate was defined as the number of cows diagnosed pregnant on day 30-35 post ovulation divided by the number of cows inseminated multiplied by 100 . Effects of treatment on conception rate were determined by the following formulae:

For pyometra, mucometra, anoestrus and poor heat detection, a case was considered cured when a cow showed estrus. In these cases-

Number of cows showed estrus after treatment

(1). Cure rate $(\%)=$

Number of cows treated $\times 100$

For endometritis, metritis, ovarian cysts and repeat breeder cows, a case was considered cured when she became pregnant. In these cases-

Number of cows became pregnant after breeding

(2). Cure rate $(\%)=$------------------------------------------ $\times 100$

Number of cows affected

\section{Results}

3.1. Proportions of reproductive disorders in cows: Out of 54 clinical cases investigated, fifteen cows $(27.8 \%$; $15 / 54)$ were suffering from endometritis, whereas $7.4 \%(4 / 54), 11.1 \%(6 / 54)$ and $3.7 \%(2 / 54)$ were suffering from metritis, pyometra, and mucometra, respectively. Follicular and luteal cysts were found in $9.2 \%(5 / 54)$ and $1.9 \%(1 / 54)$ cows respectively, mummified fetus was recorded in $1.9 \%(1 / 54)$ cows, twelve cows out of 54 were suffering from anoestrus $(22.2 \% ; 12 / 54)$, two cows $(3.7 \%, 2 / 54)$ had repeat breeding problems and poor heat detection was diagnosed in $11.1 \%(6 / 54)$ cows. A summary of the proportions of the diagnosed cases and ultrasonographic findings are shown in TABLE 3 and 4, respectively.

3.2. Reproductive performance of affected cows after treatment: In total, 6 cows were identified as normally cycling but farmers considered these cases anoestrus. These were diagnosed as cases of poor heat detection. 
Five cows out of these six responded to treatment in terms of becoming in heat giving $83.3 \%(5 / 6)$ effectiveness of the treatment. The success of the treatment was $60.0 \%$ (3/50 in case of endometritis while the efficacy of treatment was $100.0 \%$ in case of metritis. $66.7 \%(4 / 6)$ and $100.0 \%(2 / 2)$ cows became completely cured after treatment against pyometra and mucometra, respectively. The effectiveness of the treatment were $60.0 \%(3 / 5)$ and $100.0 \%$ for the cows with follicular cysts and luteal cysts, respectively. Nine anoestrus cows out of 12 showed prominent estrus signs after treatment resulting 75.0\% (9/12) efficacy of the treatment. But the cows with mummified fetus did not respond to the applied treatment. However, out of 42 , after treatment 31 cases showed estrus resulting an overall $73.8 \%$ success of the given treatment and were bred accordingly (TABLE 5).

3.3. Effects of treatment on the conception of cows after breeding: Out of forty three cows bred thirty seven became pregnant after breeding with frozen semen; hence the overall conception rate was $86.0 \%(37 / 43)$ (TABLE 6). Success of breeding was $100.0 \%(5 / 5)$ in case of poor heat detection while $84.6 \%(11 / 13)$ and $75.0 \%(3 / 4)$ for endometritis and metritis problems, respectively. Pregnancy success in the cows which received treatment for pyometra and mucometra were $100.0 \%(4 / 4)$ and $50.0 \%(1 / 2)$, respectively, after breeding. $100.0 \%$ cows conceived which were bred after treatment against follicular and luteal cysts. Conception rates for cows receiving treatment for anoestrus and repeats breeding problems and were $88.9 \%(8 / 9)$ and $50.0 \%(1 / 2)$, respectively, after breeding.

TABLE 1: Farmers' complaints about the cases of reproductive disorders in cows

\begin{tabular}{llc}
\hline Serial No. & Farmers complaints & Number of cases \\
\hline 1 & Did not show estrus by $\geq 60$ days postpartum & 24 \\
2 & Came to heat regularly but did not conceive & 17 \\
3 & Wanted to know the pregnancy status & 2 \\
4 & Irregular estrus cycle but did not conceive & 6 \\
5 & Fever, inappetance and the cow was presumably pregnant & \\
6 & Vaginal discharges but not cycling & 1 \\
\hline Total & & 54 \\
\hline
\end{tabular}

TABLE 2: Treatments given to cows with reproductive disorders diagnosed

\begin{tabular}{|c|c|c|c|}
\hline Serial No. & Diagnosis & Treatment used & No. of animals \\
\hline 1 & Poor heat detection & Advice to monitor heat carefully + AI following estrus & 6 \\
\hline 2 & Endometritis & $\begin{array}{l}\text { Intrauterine infusion with oxytetracycline }+ \text { PGF2 } \alpha \text { if CL was } \\
\text { present }+ \text { AI on observed estrus }\end{array}$ & 15 \\
\hline 3 & Metritis & Intrauterine penicillin $+\mathrm{AI}$ on observed estrus & 4 \\
\hline 4 & Pyometra & PGF2 $\alpha+$ heat monitoring + AI on observed estrus & 6 \\
\hline 5 & Mucometra & $\begin{array}{l}\text { GnRH+ PGF } 2 \alpha+\text { heat monitoring } \\
+ \text { AI on observed estrus }\end{array}$ & 2 \\
\hline 6 & Follicular cyst & GnRH+ PGF $2 \alpha+\mathrm{GnRH}$ at the time of AI & 5 \\
\hline 7 & Luteal cyst & PGF $2 \alpha+2$ times AI at 12 hour interval on the same estrus & 1 \\
\hline 8 & Mummified fetus & PGF2 $\alpha$ & 1 \\
\hline 9 & Anoestrus & $\begin{array}{l}\text { Nutritional supplementation/ } \\
\text { GnRH+ PGF2 } \alpha+\mathrm{AI}+\mathrm{GnRH}\end{array}$ & 12 \\
\hline 10 & Repeat breeder & GnRH at the time of $\mathrm{AI}$ & 2 \\
\hline
\end{tabular}

TABLE 3: Proportions of reproductive disorders in cows

\begin{tabular}{lcc}
\hline Reproductive Disorders & No. of cows examined & $\%$ \\
\hline Poor heat detection & 6 & 11.1 \\
Endometritis & 15 & 27.8 \\
Metritis & 4 & 7.4 \\
Pyometra & 6 & 11.1 \\
Mucometra & 2 & 3.7 \\
Follicular cyst & 5 & 9.2 \\
Luteal cyst & 1 & 1.9 \\
Mummified fetus & 1 & 1.9 \\
Anoestrus & 12 & 22.2 \\
Repeat breeding & 2 & 3.7 \\
\hline Total & 54 & 100.0 \\
\hline
\end{tabular}


TABLE 4: Ultrasonographic findings and diagnosis of reproductive disorders

\begin{tabular}{|c|c|c|c|c|}
\hline Farmers complaints & $\begin{array}{l}\text { Stages of cycle at } \\
\text { the time of } \\
\text { examination }\end{array}$ & Ultrasonographic findings & Diagnosis & $\begin{array}{l}\text { No. of } \\
\text { animals }\end{array}$ \\
\hline \multirow{3}{*}{$\begin{array}{l}\text { Did not show estrus } \\
\text { by Day } 60 \\
\text { postpartum }\end{array}$} & \multirow{3}{*}{$\begin{array}{l}\text { Not in estrus at the } \\
\text { time of } \\
\text { examination }\end{array}$} & $\begin{array}{l}\text { Greyish edematous endometrium with irregular, } \\
\text { greyish-black structure with echogenic spots on } \\
\text { ovary (CL). }\end{array}$ & $\begin{array}{l}\text { Poor heat } \\
\text { detection }\end{array}$ & 6 \\
\hline & & $\begin{array}{l}\text { Uterus distended and have thickened uterine wall. } \\
\text { The viscous fluid inside the lumen contained } \\
\text { diffused, echogenic particles floating in it. Presence } \\
\text { of greyish-black structure with echogenic spots in } \\
\text { the ovary (CL). }\end{array}$ & Pyometra & 6 \\
\hline & & $\begin{array}{l}\text { No echogenic area (CL) was imaged in the ovarian } \\
\text { stroma and small follicles (nonechogenic structures) } \\
(5-7 \mathrm{~mm} \text { diameter) was visible on the ovarian } \\
\text { surface. Less dark endometrium with low } \\
\text { echogenicity was found. }\end{array}$ & Anoestrus & 12 \\
\hline \multirow{3}{*}{$\begin{array}{l}\text { Came to heat } \\
\text { regularly but did not } \\
\text { conceive }\end{array}$} & \multirow{2}{*}{$\begin{array}{l}\text { Were in estrus at } \\
\text { the time of } \\
\text { examination }\end{array}$} & $\begin{array}{l}\text { Moderate amount of anechogenic fluid in lumen } \\
\text { alongwith 'snowy' echogenic particles. Uterine } \\
\text { wall was thickened. Large nonechogenic structures } \\
\text { (follicle, } 9-12 \mathrm{~mm} \text { ) found on ovary. }\end{array}$ & $\begin{array}{l}\text { Endometriti } \\
\mathrm{s}\end{array}$ & 10 \\
\hline & & $\begin{array}{l}\text { Dark edematous endometrium with nonechogenic } \\
\text { structures on ovary (follicle, } 10-11 \mathrm{~mm} \text { ). }\end{array}$ & $\begin{array}{l}\text { Repeat } \\
\text { breeder }\end{array}$ & 2 \\
\hline & $\begin{array}{l}\text { Not in estrus } \\
\text { at the time of } \\
\text { examination }\end{array}$ & $\begin{array}{l}\text { Large amount of anechogenic fluid in lumen } \\
\text { alongwith 'snowy' echogenic particles. Greyish- } \\
\text { black structure with echogenic spots (CL) on ovary. }\end{array}$ & $\begin{array}{l}\text { Endometriti } \\
\mathrm{S}\end{array}$ & 5 \\
\hline $\begin{array}{l}\text { Wanted to know the } \\
\text { pregnancy status }\end{array}$ & $\begin{array}{l}\text { Were in estrus } \\
\text { at the time of } \\
\text { examination }\end{array}$ & $\begin{array}{l}\text { Uterus was thin walled which was visible as white } \\
\text { streak and appears to be filled with echogenic } \\
\text { particles in the enormous anechoic fluid present } \\
\text { inside it. No greyish-black structure with echogenic } \\
\text { spots (CL) was found. }\end{array}$ & Mucometra & 2 \\
\hline \multirow[t]{2}{*}{$\begin{array}{l}\text { Irregular estrus cycle } \\
\text { but did not conceive }\end{array}$} & $\begin{array}{l}\text { Were in estrus at } \\
\text { the time of } \\
\text { examination }\end{array}$ & $\begin{array}{l}\text { Imaged as thin walled }(\leq 3 \mathrm{~mm}) \text { non-echogenic } \\
\text { structures visible over the surface of the ovary. Size } \\
\text { was } \geq 25 \mathrm{~mm} \text {. No greyish-black structure with } \\
\text { echogenic spots was found and uterus was dark. }\end{array}$ & $\begin{array}{l}\text { Follicular } \\
\text { cyst }\end{array}$ & 5 \\
\hline & $\begin{array}{l}\text { Not in estrus } \\
\text { at the time of } \\
\text { examination }\end{array}$ & $\begin{array}{l}\text { Anechoic central cavity bordered by a distinct wall } \\
(>3 \mathrm{~mm}) \text { of luteinized tissue imaged over the } \\
\text { ovarian surface. Size }>25 \mathrm{~mm} \text {. }\end{array}$ & Luteal cyst & 1 \\
\hline $\begin{array}{l}\text { Fever, inappetance } \\
\text { and the cow was } \\
\text { presumably } \\
\text { Pregnant }\end{array}$ & $\begin{array}{l}\text { Not in estrus at the } \\
\text { time of } \\
\text { examination }\end{array}$ & $\begin{array}{l}\text { Uterine fluids were not evident in contrast to the } \\
\text { snowy appearance of the lumen of uterus. Uterine } \\
\text { wall was thickened. Fetal parts were rarely } \\
\text { identified and mostly appeared as a poorly defined } \\
\text { echogenic mass. }\end{array}$ & $\begin{array}{l}\text { Mummified } \\
\text { fetus }\end{array}$ & 1 \\
\hline $\begin{array}{l}\text { Vaginal discharges } \\
\text { but not cycling }\end{array}$ & $\begin{array}{l}\text { Not in estrus at the } \\
\text { time of } \\
\text { examination }\end{array}$ & $\begin{array}{l}\text { Uterine wall was thickened and uterine body was } \\
\text { distended. Enormous amount of anechoic fluid was } \\
\text { present in the lumen along with echogenic particles. } \\
\text { Greyish-black structure with echogenic spots (CL) } \\
\text { in one ovary, in another ovary, no significant } \\
\text { structures (NSS) was found. }\end{array}$ & Metritis & 4 \\
\hline
\end{tabular}

TABLE 5: Effects of treatment on resumption of estrous cycle

\begin{tabular}{lccc}
\hline \multicolumn{1}{c}{ Reproductive Disorders } & $\begin{array}{c}\text { No. of cows } \\
\text { treated }\end{array}$ & $\begin{array}{c}\text { No. of cows } \\
\text { in estrus }\end{array}$ & \% of cows in heat estrus \\
\hline Poor heat detection & 6 & 5 & 83.3 \\
Endometritis & 5 & 3 & 60.0 \\
Metritis & 4 & 4 & 100.0 \\
Pyometra & 6 & 4 & 66.7 \\
Mucometra & 2 & 2 & 100.0 \\
Follicular cyst & 5 & 3 & 60.0 \\
Luteal cyst & 1 & 1 & 100.0 \\
Mummified fetus & 1 & 0 & 0 \\
Anoestrus & 12 & 9 & 75.0 \\
\hline & & Total: 31 & Overall: 73.8 \\
\hline
\end{tabular}




\section{TABLE 6: Pregnancy rate of cows of different disorders after treatment and breeding}

\begin{tabular}{lccc}
\hline \multicolumn{1}{c}{ Reproductive disorders } & $\begin{array}{c}\text { No. of cows } \\
\text { bred }\end{array}$ & $\begin{array}{c}\text { No. of Cows } \\
\text { pregnant }\end{array}$ & $\begin{array}{c}\text { \% of pregnant cows (Conception } \\
\text { rate) }\end{array}$ \\
\hline Poor heat detection & 5 & 5 & 100.0 \\
Endometritis & 13 & 11 & 84.6 \\
Metritis & 4 & 3 & 75.0 \\
Pyometra & 4 & 4 & 100.0 \\
Mucometra & 2 & 1 & 50.0 \\
Follicular cyst & 3 & 3 & 100.0 \\
Luteal cyst & 1 & 1 & 100.0 \\
Anoestrus & 9 & 8 & 88.9 \\
Repeat breeding & 2 & 1 & 50.0 \\
\hline
\end{tabular}

\section{Discussion}

An overwhelming proportion of animals that farmers considered as anoestrus cows had CL when examined by ultrasonography. These animals were in fact cycling but the farmers failed to detect them in estrus. This indicates poor heat detection in six cows (11.1\%) out of 54. When the estrus signs of these cows were monitored carefully and bred at each observed estrus, they responded to treatment and conceived. Five cows out of these six responded to treatment in terms of becoming in heat giving $83.3 \%(5 / 6)$ effectiveness of the treatment and five became pregnant giving $100.0 \%$ conception rate (5/5).In a previous study, Kamal et al [6] reported that $11.0 \%$ cows had CL at the time of examination but farmers presented those animals as not seen in estrus. Poor follicular growth, no CL, inactive ovaries, poor body condition led most of the cows to become anoestrus as evidenced in this study. All these had negative effects on conception rate and also reported earlier by Shamsuddin and Aryal, [15]. Twelve cows were suffering from anoestrus $(22.2 \% ; 12 / 54)$ whereas two cows $(3.7 \% ; 2 / 54)$ had repeat breeding problems. Incidence of anoestrus in dairy herds over multiple years varied from 11 to $92 \%$ [20] and also $18.5 \%$ [6]. Repeat breeding in cows in various countries ranged from 10.0 to $18.0 \%$ [8]. Nine anoestrus cows out of 12 showed prominent estrus signs after treatment and the treatment efficacy was $75.0 \%$. Conception rates were $88.9 \%(8 / 9)$ and $50.0 \%(1 / 2)$, respectively for cows receiving treatment against anoestrus and repeat breeding problems. Conception rates 66.7 to $80.0 \%$ were also reported for anoestrus and repeat breeder cows in several independent previous studies [18, 21].

Endometritis was the most frequently diagnosed pathological conditions and most of the farmers presented these cows as repeat breeder animals. The presence of anechoic fluid in cases of endometritis along with snowy echogenic particles observed during this study was similar to previous reports [10]. Fifteen cows among $54(27.8 \%)$ were suffering from endometritis. These animals had apparently normal cervical and vaginal discharges. Kamal et al [6] reported 3.0\% prevalence of endometritis in cows while Ali and Timimi [1] found $13.9 \%$ endometritis in cows. Metritis was diagnosed in four cows $(7.4 \% ; 4 / 54)$ which corroborated with previous report of Kumar and Purohit [10] and also with Ali and Timimi [1] who reported 8.3\% metritis in cows. The ultrasonographic features of metritis were in part similar to endometritis; however, there was enormous amount of anechoic fluid in the distended uterus along with echogenic particles falling in line with features reported by others [11]. The successes of the treatment were $60.0 \%(3 / 5)$ and $100.0 \%(4 / 4)$ against endometritis and metritis, respectively. In case of endometritis, $84.6 \%(11 / 13)$ cows conceived and got pregnant after breeding which was $75.0 \%$ (3/4) for the cows with metritis problem. This result is closely similar to the findings of Shamsuddin et al [18] who reported $78.5 \%$ (11/14) conception rate after treating the uterine infections like metritis and endometrtis. In cases of pyometra, ultrasonographically, high volumes of echogenic pus, presence of cotyledons inside the uterus and CL on the ovary were observed in this study which is similar to the findings of Sheldon et al [19]. Most of these cases were in fact presented as anoestrus cows. Subsequent to therapy, the uterine diameter, fluid accumulation and echogenic particles got reduced which was also recorded by Kumar and Purohit [10]. In cases of mucometra, in accordance with present study, a consistent ultrasonographic finding was thin walled uterus filled with anechoic fluid [3]. Among the diagnosed cases, $11.1 \%(6 / 54)$ cows were found suffering from pyometra and $3.7 \%(2 / 54)$ from mucometra. After proper treatment and management $66.7 \%(4 / 6)$ and $100.0 \%(2 / 2)$ cows with pyometra and mucometra, respectively, cured and resulted pregnancy in $100.0 \%(4 / 4)$ and $50.0 \%(1 / 2)$ cows, respectively. Kumar et al [9] found $62.50 \%$ and $50.00 \%$ conception rate, respectively for uterine infection with thin and thick cervical mucous.

The ultrasonographic features of cysts were simple fluid filled (anechoic) thin walled structures $25 \mathrm{~mm}$ (follicular cysts) round to ovoid in shape. The diameters of ovarian cysts varied from $30 \mathrm{~mm}$ to $48 \mathrm{~mm}$. Luteal cysts were characterized by the presence of a distinct hypoechoic wall $(3 \mathrm{~mm})$, which was used to differentiate luteal cysts from follicular cysts. These are in agreement with findings published elsewhere [12]. Six ovarian 
cysts (follicular cysts; $9.2 \%$ and luteal cysts; $1.9 \%$ ) were diagnosed in this study. A higher incidence of follicular cysts and lower incidence of luteal cysts had been recorded elsewhere [10]. Treatment of ovarian cysts with GnRH and PGF2 $\alpha$ resulted in re-establishment of normal estrous cycles within 12 days. The effectiveness of the treatment were $60.0 \%(3 / 5)$ and $100.0 \%$ for the cows with follicular cysts and luteal cysts, respectively. When these cyclic cows were bred following estrus with single dose of GnRH, $100.0 \%$ cows became pregnant. Khurshid and Anjum [7] reported that administration of GnRH and PGF2 $\alpha$ resulted $80.0 \%$ conception rate in cows with cystic ovarian diseases. The response to the treatment was good as evident by the ultrasonographic disappearance of both the type of cysts within 12-40 days of treatment, which confirmed previous reports [22]. But the cows with mummified fetus did not respond to the applied treatment.

\section{Conclusion}

Ultrasonography can be performed at individual and farm level to diagnose different reproductive tract disorders and also to determine the proportions of different reproductive disorders in dairy cows. Furthermore, treatment outcome for the improvement of fertility and conception rate could be monitored by the application of ultasonography. Thus, ultrsonography is becoming the first choice for sustainable improvement in the reproductive management program of dairy farms.

\section{References}

[1] T.Gh.M. Ali and I.H. Al-Timimi, Effect of treated genital diseases on the number of services per conception in dairy cattle, $A L$ Qadysia Journal for Veterinary Medical Science, 2011, 10: 1.

[2] P.D. Carriere, L. DesCoteaux, and J. Durocher, Evaluation echographique du tractus reproducteur bovin: Developpement normal et anormal des follicules ovariens et du corps jaune, Médecins Vétérinaires du Québec, 32, 2002, 128-131.

[3] R.A. Fissore, A.J. Edmondson, R.L.Pashen and R.H. Bondurant, The use of ultrasonography for the study of the bovine reproductive tract II. Non pregnant, pregnant and pathological conditions of the uterus, Animal Reproduction Science, 2, 1986, 167177.

[4] P.M. Fricke, D.Z. Caraviello, K.A. Weigel and M.L. Welle, Fertility of dairy cows after resynchronization of ovulation at three intervals after first timed insemination, Journal of Dairy Science, 86, 2003, 3941-3950.

[5] M.R. Jainudeen and E.S.E. Hafez, Reproductive cycles in cattle and buffaloes. In: Hafez ESE, Hafez B (Eds.), Reproduction in Farm Animals (7th Edn.), Lea and Febiger, Baltimore, Maryland, USA, pp 297-314, 2000.

[6] M.M. Kamal, M.M. Rahman, H.W. Momont and M. Shamsuddin, Underlying Disorders of Postpartum Anoestrus and Effectiveness of their Treatments in Crossbred Dairy Cows, Asian Journal of Animal Science, 6, 2012, 132-139.

[7] A.S. Khurshid and A. Anjum, Management of some ovarian disorders in post-partum crossbred cows, Online Veterinary Journal (Vet Scan), 7(1), 2012, 111.

[8] M. Kimura, T. Nakao, M. Moriyoshi and K. Kawata, Luteal phase deficiency as a possible cause of repeat breeding in dairy cows, British Veterinary Journal, 43, 1987, 560-566.

[9] R. Kumar, D. Kumar and B. Roy, Studies on repeat breeding of buffaloes, Buffalo Bulletin, 30, $2011,3$.

[10] V. Kumar and G.N. Purohit, Ultrasonographic diagnosis of the bovine genital tract disorders, Online Veterinary Journal (Vet Scan), 4(2), 2009, 43

[11] P. Melendez, J. McHale, J. Bartolome, L.F. Archbald and G.A. Donovan, Uterine involution and fertility of Holstein cows subsequent to early postpartum PGF2alpha treatment for acute puerperal metritis, Journal of Dairy Science, 7, $2004,3238-3246$.

[12] S.B. Naoki, Follicular cysts in dairy cows, Journal of Animal Science, 78, 2007, 1-6.

[13] R.A. Pierson, J.P. Kastelic and O.J. Ginther, Basic principles and techniques for transrectal ultrasonography in cattle and horses, Theriogenology, 29, 1988, 3-20.

[14] M.C. Pieterse, O. Szenci, A.H. Willemse, C.S.A. Bajcsy, S.J. Dieleman and M.A.M. Taverne, Early pregnancy diagnosis in cattle by means of linear-array real-time ultrasound scanning of the uterus and qualitative and quantitative milk progesterone test, Theriogenology, 33, 1990a, 697-707.

[15] M. Shamsuddin and M.P. Aryal, Nutrition and reproductive management. In. Robinson PH and Krishnamoorthy U (eds). Handbook of Dairy Nutrition: Bangladesh, American Soybean Association-International Marketing, New Delhi, India, pp 208-215, 2010.

[16] M. Shamsuddin, M.M.U. Bhuiyan, T.K. Sikder, A.H. Sugulle, P.K. Chanda, M.G.S. Alam and D. Galloway, Constraints limiting the efficiency of artificial insemination of cattle in Bangladesh. In: Radioimmunoassay and Related Techniques to Improve Artificial Insemination Programmes for Cattle Reared under Tropical and Sub-tropical Conditions, IAEA-TECDOC-1220, IAEA, Vienna, pp 9-27, 2001.

[17] M. Shamsuddin, W.J. Goodger, M.S. Hossein, T. Azizunnesa and N.K. Bennett, A survey to identify economic opportunities for smallholder dairy farms in Bangladesh, Tropical Animal Health and Production, 8, 2006a, 131-140.

[18] M. Shamsuddin, M. S. Hossein, M.A.R. Siddiqui, A.H.M.S.I. Khan, F.Y. Bari, M.F. Alam, M. Rahman, A.S.M. Sayem and H. Momont, Use of milk progesterone radioimmunoassay and computer applications for community based reproductive health services in smallholder dairy farms of Bangladesh, IAEA-TECDOC-1533, May 2007, IAEA, Vienna, pp 9-22, 2007.

[19] I.M. Sheldon, G.S. Lewis, S. LeBlanc and R.O. Gilbert, Defining postpartum uterine disease in cattle, Theriogenology, 65, 2006, 1516-1530.

[20] J.S. Stevenson, K. Sandra, H. Johnson and A.M. George, Incidence of postpartum anoestrus in suckled beef cattle: Treatments to induce estrus, ovulation and conception, Proceedings of the Applied Reproductive Strategies in Beef Cattle Workshop, pp 5-6 September, 2002, Manhattan, Kansas, 2002.

[21] A.A. Vamerzani, B.M. Dubey and D.V. Arneja, Clinical response of normal and repeat breeder crossbred cows to receptal therapy, International Journal of Animal Science, 14, 1999, 113-116.

[22] Y. Yavas and J.S. Walton, Induction of ovulation in postpartum suckled beef cows: a review, Theriogenology, 54, 2000, 1-23. 